\title{
Effect of physical form of forage on performance, feeding behavior, and digestibility of Holstein calves
}

\author{
C. Montoro, ${ }^{*}$ E. K. Miller-Cushon, $†$ T. J. DeVries, $\nmid$ and A. Bach* $\ddagger^{1}$ \\ *Department of Ruminant Production, Institut de Recerca i Tecnologia Agroalimentàries (IRTA), 08140 Caldes de Montbui, Spain \\ †Department of Animal and Poultry Science, University of Guelph, Kemptville, Ontario, Canada, K0G 1J0 \\ łInstitució Catalana de Recerca i Estudis Avançats (ICREA), 08010 Barcelona, Spain
}

\section{ABSTRACT}

The physical form of forage may influence rumen development and, consequently, the body weight gain, dry matter (DM) consumption, digestibility, and welfare of dairy calves. The objective of this study was to determine the effect of 2 different physical forms of forage on performance, apparent digestibility, and feeding behavior of young calves. Twenty Holstein male calves $(46.8 \pm 1.2 \mathrm{~kg})$ were randomly assigned at birth to 1 of 2 feeding treatments in which they were exposed to a mixed ration containing (on a DM basis) $90 \%$ crumb starter concentrate and either (1) $10 \%$ coarsely chopped (3 to $4 \mathrm{~cm}$ ) grass hay (CRS; $\mathrm{n}=10)$ or (2) $10 \%$ finely ground $(2 \mathrm{~mm})$ grass hay $(\mathrm{FN} ; \mathrm{n}=10)$. All calves were offered $8 \mathrm{~L} / \mathrm{d}$ of milk replacer (MR; $1.2 \mathrm{~kg}$ of $\mathrm{DM}$ ) from birth; the amount of MR was progressively reduced after 5 wk to enable weaning by the end of wk 7 . The study finished after wk 8. Consumption of the mixed ration, MR, and water was recorded daily, and calves were weighed twice weekly. Samples of feed and orts were taken in wk 7 and 8 for nutrient content analysis. Behavioral data for each calf were obtained for $2 \mathrm{~h} / \mathrm{d}$ during wk 6 and 8 , for a total observation time per animal of $28 \mathrm{~h}$. Total feces were collected during wk 8 to determine apparent digestibility. Calves fed CRS had greater DM intake than those fed FN (2.70 vs. $2.45 \pm 0.11 \mathrm{~kg} / \mathrm{d}$, respectively) during the week after weaning (wk 8). Body weight gain was similar between treatments; however, calves fed CRS tended to have a greater gain-to-feed ratio than calves fed $\mathrm{FN}(0.68$ vs. $0.63 \pm 0.02 \mathrm{~kg}$ of gain $/ \mathrm{kg}$ of DM intake). No differences were observed in crude protein and acid detergent fiber consumption between treatments; however, calves fed CRS tended to consume more neutral detergent fiber than calves fed FN during the last week of the study (719.2 vs. 610.5 $\pm 25.84 \mathrm{~g} / \mathrm{d}$ ). Calves receiving CRS sorted in favor of

Received May 15, 2012.

Accepted September 26, 2012.

${ }^{1}$ Corresponding author: alex.bach@irta.cat neutral detergent fiber to a greater extent than calves consuming FN, whereas calves fed FN sorted in favor of crude protein to a greater extent than calves fed CRS. Apparent DM, crude protein, neutral detergent fiber, and acid detergent fiber digestibility values were greater in calves fed CRS than in those fed FN $(72.3$, $77.4,40.7$, and $42.7 \%$ vs. $69.2,74.5,34.0$, and $35.6 \%$, respectively). Calves fed FN spent more time performing nonnutritive oral behaviors than those fed CRS, and calves fed FN tended to spend less time idle (either lying or standing) than those fed CRS. In conclusion, providing chopped hay to young calves improved feed intake, DM, crude protein, neutral detergent fiber, and acid detergent fiber digestibility values during the week after weaning, and reduced nonnutritive oral behaviors compared with offering ground hay.

Key words: calf, forage, physical form

\section{INTRODUCTION}

Ingestion of solid feed is necessary to stimulate rumen development in the young calf and facilitate the transition from a preruminant to a functioning ruminant. This transition involves changes in the intestinal tract because tissues must convert from reliance on glucose supplied from milk to the use of short-chain fatty acids as primary energy substrates (Baldwin et al., 2004). In the preweaned dairy calf, the intake of solid feed, particularly feed high in carbohydrates, stimulates rumen microbial proliferation and VFA production, which subsequently stimulates the development of rumen papillae (Sander et al., 1959; Warner, 1991). However, feeding concentrate, which is high in rapidly fermentable carbohydrates, can also cause reduced ruminal $\mathrm{pH}$ (Beharka et al., 1998) and rumen motility (Clarke and Reid, 1974), and it may cause overgrowth and keratinization of ruminal papillae (Bull et al., 1965), impairing absorption of VFA in the rumen (Hinders and Owen, 1965). Although forage intake contributes less to rumen papillae development (Tamate et al., 1962), forage stimulates development of the rumen muscular layer. Furthermore, forage intake promotes rumination 
(Hodgson, 1971; Phillips, 2004) and maintains the integrity and health of the rumen wall (Suárez et al., 2007). Providing texturized starter feeds is thought to improve rumen development and growth; however, the concept of "texturized" is vague and not all texturized starters seem to perform equally. Many texturized starters are available in the market, and it is difficult to predict whether a given texturized starter feed will produce the benefits commonly associated with these types of starters. Forage feeding has been discouraged during the milk-feeding phase, based on research showing low starter intake and poor BW gains in calves provided access to forage (Warner et al., 1956; Stobo et al., 1966). However, more recent studies have shown that introducing forage during the milk-feeding period improves ADG (mainly because of an increase in reticulorumen growth) and total DMI (Khan et al., 2011). Furthermore, offering hay has been reported to improve feed efficiency when feeding texturized starters (Coverdale et al., 2004; Khan et al., 2011). Similar benefits of forage provision have been reported when feeding pelleted starter feeds containing $18 \%$ NDF on a DM basis (Castells et al., 2012). Thus, offering a forage source may allow feeding low-NDF starter feeds (which may potentially impair rumen health) and improve growth rate of young calves. The comparison of feeding starter feeds alone or in combination with forage has generated some debate regarding the potential underlying effect of differences in gut fill masking some of the growth and efficiency parameters of calves (Bach et al., 2007; Kertz, 2007; Khan et al., 2012). However, measuring gut fill in vivo is impossible, and postmortem provides only information about how much feed was in the gut at the moment of slaughter (which depends not only on passage rate, but also on the amount of feed consumed before slaughter).

In addition to forage content of the diet, particle size influences the ruminal environment, VFA production, and papillae structure and function. Feeding diets that are chopped or ground to fine particle sizes results in decreased rumen $\mathrm{pH}$ and cellulolytic bacteria populations (Beharka et al., 1998). Particle size clearly affects rumen environment; however, it is unclear whether fiber particle size or total fiber content of preweaned calf diets has the greatest influence on early rumen development. Considering the need to optimize the solid feed consumption and rumen development of young calves, the objective of this study was to evaluate the effects of particle size of forage mixed with a starter concentrate on calf performance, digestibility, and feeding behavior. The hypothesis of this study was that forage particle size would influence rumen development of dairy calves, and would be reflected in increased feed consumption and improved performance for calves consuming longer forage particles.

\section{MATERIALS AND METHODS}

\section{Animals and Housing}

Twenty Holstein male calves $(46.8 \pm 1.2 \mathrm{~kg})$ participated in this study. Calves received colostrum (at least $4 \mathrm{~L}$ within the first $12 \mathrm{~h}$ of life) and were enrolled in the study within $48 \mathrm{~h}$ of birth. All calves received injections of $2 \mathrm{~mL}$ of a vitamin supplement containing vitamins A, D, and E (E-Master; Vétoquinol Canada Inc., Lavaltrie, QC, Canada), $1 \mathrm{~mL}$ of selenium (Dystosel; Pfizer Animal Health, Kirkland, QC, Canada), and $1 \mathrm{~mL}$ of a broad-spectrum antibiotic (Draxxin, tulathromycin; Pfizer Animal Health) on the day they were placed on the study. One calf experienced scours for more than 1 $\mathrm{d}$ and was therefore treated with electrolytes; however, no scouring occurred past the first 2 wk of life, and no further cases of illness requiring treatment occurred.

Calves were housed in individual pens $(1.2 \mathrm{~m}$ wide $\times 1.8 \mathrm{~m}$ deep) at the University of Guelph Kemptville Campus Dairy Education and Research Centre (Kemptville, ON, Canada) and were managed according to the standard operating procedures of this research station and following the guidelines set by the Canadian Council on Animal Care (CCAC, 2009). The pens prevented physical contact between calves but allowed for them to be in visual and auditory range. As per standard operating procedures on the research farm, pens were bedded with straw during the first $5 \mathrm{~d}$ of life, and then bedding was replaced with wood shavings. Bedding was replenished and replaced as needed, with fresh bedding added weekly at a minimum. The insides of the pens were cleaned twice a week before weaning and weekly after weaning. Pens were located under a 3-sided, roofed shelter to protect from excessive exposure to the weather.

\section{Milk-Feeding Procedure}

During the milk-feeding period, calves were fed acidified MR by teat. The feeding setup involved a rubber teat protruding into the side of the pen, attached to a tube fitted with a 1-way valve running into buckets placed adjacent to the pens. All buckets, lines, and teats were removed for cleaning before each feeding. Calves were fed a $22 \% \mathrm{CP}$ and $18 \%$ fat MR (Shur-Gain High-Performance Milk Replacer; Nutreco Canada Inc., Guelph, ON, Canada). Each liter of prepared MR contained $150 \mathrm{~g}$ of powder; the powder was combined with hot water at a rate of $150 \mathrm{~g}$ of powder per $0.25 \mathrm{~L}$, with 
additional cold water added to reach the final volume. Milk replacer was mixed daily in sufficient volume to feed all calves. At the time of preparation, a prediluted form of formic acid (acidified milk solution, 9.8\% formic acid; NOD Apiary Products Ltd., Frankford, ON, Canada) was added to acidify the MR to a target $\mathrm{pH}$ between 4.0 and 4.3. All calves were fed twice daily, at 0800 and $1600 \mathrm{~h}$, a fixed amount of $4 \mathrm{~L}$ (total $1.2 \mathrm{~kg} / \mathrm{d}$ of DM) for the first $35 \mathrm{~d}$ ( $5 \mathrm{wk})$. The amount of MR offered was decreased to $6 \mathrm{~L} / \mathrm{d}(0.9 \mathrm{~kg} / \mathrm{d}$ of DM) from d 36 to 38 and to $4 \mathrm{~L} / \mathrm{d}(0.6 \mathrm{~kg} / \mathrm{d}$ of $\mathrm{DM})$ from d 39 to 41 , and was progressively decreased daily during wk 7 to facilitate weaning by $\mathrm{d} 49$.

\section{Treatments}

Calves were randomly assigned to a mixed ration containing (on a DM basis) either (1) 90\% crumb starter concentrate and 10\% chopped (3 to $4 \mathrm{~cm}$ ) grass hay [coarse $(\mathbf{C R S}) ; \mathrm{n}=10$ ] or (2) $90 \%$ crumb starter concentrate and $10 \%$ ground $(2 \mathrm{~mm})$ grass hay [fine $(\mathbf{F N}) ; \mathrm{n}=10]$. The CRS grass hay was chopped using a New Holland 355 grinder-mixer (New Holland Inc., New Holland, PA) to pass through a 4-cm mesh, whereas the FN grass hay was chopped using a Wiley mill (Arthur H. Thomas Co., Philadelphia, PA) to pass through a 2-mm mesh. Ninety-five percent of the particles of the crumb starter were retained in a $1.18-\mathrm{mm}$ mesh but passed through an 8-mm mesh. Birth weights were similar $(P=0.7)$ for calves in both the CRS (45.8 $\pm 1.6 \mathrm{~kg}$ ) and FN $47.9 \pm 1.8 \mathrm{~kg}$ ) treatments. Solid feed (Table 1) was offered ad libitum in circular buckets (diameter $=25.4 \mathrm{~cm}$, height $=23.0 \mathrm{~cm})$ attached to the front of the pen, beginning on d 5 of the study.

\section{Measurements, Sample Collection, and Analysis}

Calves were weighed at the same time each day on 2 consecutive days each week. Repeated measurements were made to obtain an accurate weekly weight and to account for day-to-day variability. Throughout the study, MR, water, and TMR (starter feed + grass hay) consumption were recorded daily on an individual basis. As a consequence of the low temperatures (average minimum temperature was $-13^{\circ} \mathrm{C}$ during the first $30 \mathrm{~d}$ of the study), water was often frozen during the first month of the study. Therefore, water consumption data refer only to measurements obtained between d 31 and 56. To determine DMI, fresh concentrate, fresh forage, fresh mixed rations, and orts from all calves were sampled twice weekly throughout the study. In addition, during wk 7 and 8 , fresh concentrate, fresh forage, fresh mixed rations, and ort samples from all calves were obtained daily. All samples were immediately frozen at $-20^{\circ} \mathrm{C}$ until subsequent analyses.

Samples for particle size analysis were separated using the 3 -screen $(19,8$, and $1.18 \mathrm{~mm})$ Penn State Particle Separator (Kononoff et al., 2003), which separated particles into 4 fractions: long $(>19 \mathrm{~mm})$, medium $(<19$, $>8 \mathrm{~mm})$, short $(<8,>1.18 \mathrm{~mm})$, and fine $(<1.18 \mathrm{~mm})$ particles. Feed samples obtained for DM and chemical analyses were oven-dried at $55^{\circ} \mathrm{C}$ for $48 \mathrm{~h}$. During wk 7 and 8 , samples of fresh feed were collected twice a week and pooled by animal and week to determine nutrient contents. Also during these $2 \mathrm{wk}$, orts were collected on a daily basis and pooled by animal and week. Because the amount of orts differed within animal and day, samples were pooled proportionally to the amount left over (15\% of daily orts). The week after weaning (49 d of age), plastic bags were glued to the perianal region of each calf, as described elsewhere (Terré et al., 2007), to determine apparent DM, CP, NDF, and ADF digestibility values of the diets. During wk 8 of the study, all feces were collected and weighed. Bags were changed at least 4 times per day. For each calf, a daily subsample equivalent to $30 \%$ of total feces collected was obtained and dried at $60^{\circ} \mathrm{C}$ for $72 \mathrm{~h}$. Subsamples were pooled by calf for further analysis. Feed and fecal samples collected to determine nutrient content were ground to pass through a 1-mm screen (Wiley mill;

Table 1. Chemical composition of feed components and mixed rations (mean $\pm \mathrm{SD}$ )

\begin{tabular}{lcccc}
\hline Item & Concentrate $^{1}$ & Hay $^{2}$ & Coarse feed $^{3}$ & Fine feed $^{4}$ \\
\hline $\mathrm{DM}, \%$ & $89.2 \pm 0.75$ & $88.5 \pm 1.13$ & $89.3 \pm 0.30$ & $89.4 \pm 0.41$ \\
$\mathrm{CP}, \%$ of DM & $24.7 \pm 0.60$ & $12.3 \pm 0.30$ & $23.6 \pm 0.72$ & $23.3 \pm 0.53$ \\
$\mathrm{ADF}, \%$ of DM & $11.1 \pm 0.37$ & $44.3 \pm 1.38$ & $13.6 \pm 0.75$ & $14.4 \pm 0.56$ \\
$\mathrm{NDF}, \%$ of DM & $21.0 \pm 0.90$ & $64.8 \pm 1.27$ & $25.9 \pm 1.73$ & $25.5 \pm 0.86$ \\
Ash, \% of DM & $9.6 \pm 0.21$ & $14.2 \pm 2.03$ & $9.7 \pm 0.17$ & $9.7 \pm 0.10$ \\
\hline${ }^{1}$ Concentrate was a dairy calf crumb starter (Shur-Gain; Nutreco Canada Inc., Guelph, ON, Canada). \\
${ }^{2}$ Hay was a second cut of ryegrass hay. \\
${ }^{3}$ Coarse feed contained 90\% concentrate and 10\% hay chopped at approximately 3 to $4 \mathrm{~cm}$. Particle size $=0.6 \%$ \\
$>8$ mm; 94.2\% <8, $>1.18$ mm; 5.2\% <1.18 mm. \\
${ }^{4}$ Fine feed contained 90\% concentrate and 10\% hay ground at approximately 2 mm. Particle size $=88.8 \%<8$, \\
$>1.18$ mm; $11.2 \%<1.18$ mm.
\end{tabular}


Arthur H. Thomas Co.) and sent to Cumberland Valley Analytical Services Inc. (Maugansville, MD) for analysis of $\mathrm{DM}\left(135^{\circ} \mathrm{C}\right.$; AOAC International, 2000: method 930.15), ash $\left(535^{\circ} \mathrm{C}\right.$; AOAC International, 2000: method 942.05), ADF (AOAC International, 2000: method 973.18), NDF with heat-stable $\alpha$-amylase and sodium sulfite (Van Soest et al., 1991), and $\mathrm{CP}(\mathrm{N} \times 6.25$; AOAC International 2000: method 990.03; Leco FP-528 Nitrogen Analyzer, Leco, St. Joseph, MI).

\section{Animal Behavior}

Behavior was monitored by direct observations of all calves for 2 periods of $7 \mathrm{~d}, 2 \mathrm{wk}$ before weaning (wk 6 ) and during the week after weaning (wk 8). Calves were observed $1 \mathrm{~h}$ immediately after the morning MR feeding (at $0830 \mathrm{~h}$ ) and $1 \mathrm{~h}$ after solid feed was weighed and offered (at $1030 \mathrm{~h}$ ) during the preweaning week. Although no MR was provided in the second observation week, calves were observed at the same times as in wk 6 . Total observation time per animal was $28 \mathrm{~h}$ for the entire monitoring period. Instantaneous scans were performed at intervals of $60 \mathrm{~s}$ for occurrences of lying and standing and the following behaviors: eating, drinking, ruminating, performing nonnutritive oral behaviors (licking any surface, tongue rolling, or consuming wood shavings), head butting (when the animal pressed any surface with its head), and idling (when none of the above behaviors was being performed).

\section{Calculations and Statistical Analysis}

Weekly ADG was calculated as the difference between BW taken 1 wk apart divided by 7 . Gain-to-feed ratio was calculated for each week by dividing BW gained in that week by total DMI in that week. Apparent nutrient digestibility values were calculated as the difference between the quantity of a nutrient consumed and the quantity of that nutrient defecated, divided by the quantity of that nutrient consumed. Sorting activity during wk 7 and 8 for individual nutrients was calculated as the actual intake of each nutrient expressed as a percentage of the predicted intake of that nutrient. The actual intake of each nutrient was calculated as the difference between the amount of each nutrient in the feed offered and that in the feed refused. The predicted intake for an individual nutrient was calculated as the product of DMI of the total diet times the percentage of that nutrient in the offered mixed feed. Values equal to $100 \%$ indicate no sorting, those $<100 \%$ indicate selective refusals (sorting against), and those $>100 \%$ indicate preferential consumption (sorting for). Similarly, sorting was calculated for each fraction of the Penn State Particle Separator.
Data for DMI, ADG, and gain-to-feed ratio were summarized for each calf by week. Data for nutrient intakes and sorting activity for individual nutrients were analyzed for wk 7 and 8. Sorting activity for each nutrient was tested for a difference from $100 \%$ by using the TTEST procedure of SAS (SAS Institute Inc., Cary, NC). All data were analyzed with a mixed-effects model for repeated measures, except apparent nutrient digestibility data. The statistical model included the fixed effects of week, treatment, and week $\times$ treatment interaction, and the random effect of calf within treatment. Differences in apparent nutrient digestibility between treatments were analyzed by using a simple $t$-test.

Behavioral data were summarized individually as the total time (min) devoted to each monitored behavior per day. Data for standing, lying, idling, eating, and performance of nonnutritive oral behaviors were analyzed with a mixed-effects model for repeated measures. The statistical model included the fixed effects of day, treatment, and their 2-way interaction and the random effect of calf within treatment. Because of the lack of normality, data from nonnutritive oral behaviors were square-root transformed. Least squares means presented for nonnutritive oral behaviors correspond to nontransformed data, and standard errors of the means and $P$-values correspond to the results from the mixed-effects model using square-root data. Ruminating, drinking, and head-butting behavioral data were analyzed with a mixed-effects Poisson regression model that included calf as a random effect and treatment, time (day), and the interaction between treatment and day as fixed effects.

\section{RESULTS AND DISCUSSION}

\section{Apparent Nutrient Digestibility}

Total tract apparent digestibility values of DM, CP, $\mathrm{ADF}$, and NDF during the week after weaning (wk 8) were greater in calves offered CRS diets than in those offered FN diets (Table 2). This may also explain the tendency for an improved apparent feed efficiency in calves fed CRS compared with those fed FN (Table 3). Apparent nutrient digestibility values observed herein are in the range previously reported in weaned calves (Terré et al., 2007; Hill et al., 2010; Castells et al., 2012). It seems that particle size of forage may play an important role in nutrient digestibility. In the present study, despite the fact that calves fed CRS consumed more NDF than calves fed FN, apparent digestibility values of DM, CP, ADF, and NDF were greater in calves fed CRS than in those fed FN. It could be speculated that the presence of chopped hay in the diet 
Table 2. Total tract nutrient apparent digestibility during the week after weaning (wk 8) of calves fed mixed rations containing chopped or ground hay

\begin{tabular}{|c|c|c|c|c|}
\hline \multirow[b]{2}{*}{ Item } & \multicolumn{2}{|c|}{ Treatment $^{1}$} & \multirow[b]{2}{*}{ SE } & \multirow[b]{2}{*}{$P$-value } \\
\hline & CRS & $\mathrm{FN}$ & & \\
\hline DM, \% & 72.3 & 69.2 & 0.68 & $<0.01$ \\
\hline $\mathrm{CP}, \%$ & 77.4 & 74.5 & 0.86 & 0.03 \\
\hline $\mathrm{ADF}, \%$ & 40.7 & 34.0 & 2.18 & 0.04 \\
\hline NDF, $\%$ & 42.7 & 35.6 & 2.11 & 0.03 \\
\hline
\end{tabular}

${ }^{1} \mathrm{CRS}=$ mixture of $90 \%$ concentrate and $10 \%$ chopped (3 to $4 \mathrm{~cm}$ ) hay (coarse); FN = mixture of $90 \%$ concentrate and $10 \%$ ground $(2 \mathrm{~mm})$ hay (fine).

was associated with an improved rumen environment, which would ultimately lead to an overall improvement in digestibility. However, it could also be possible that CRS increased retention time and that would improve apparent digestibility, although this is unlikely because DMI did not differ between treatments (Table 3).

\section{Performance and Sorting}

Intakes and performance data are reported in Table 3. No treatment differences were observed in water, MR consumption, solid feed intake, and total DMI. However, solid feed intake was subject to a treatment $\times$ week interaction; in the first week after weaning (wk 8), calves receiving CRS had greater DMI than calves receiving FN (Figure 1). Both treatments had similar ADG during the study (Table 3). It is interesting that calves offered CRS tended to be more efficient than calves offered FN. It is likely that the presence of chopped hay in the CRS diet improved the development of the reticulorumen (Khan et al., 2011), promoting salivary flow to the rumen through greater initial mastication and increased rumination (van Ackeren et al., 2009; Khan et al., 2011; Castells et al., 2012).
An improved rumen environment may have, in turn, contributed to the increased intake of solid feed during the week after weaning and to the trend for an overall improvement in feed efficiency. Several researchers (Thomas and Hinks, 1982; Davis and Drackley, 1998) have reported that DMI increased when incorporating between 10 and $25 \%$ of ground or chopped hay or straw into a complete diet. Coverdale et al. (2004) reported that the addition of hay to diets appeared to favorably alter the rumen environment, resulting in increased intake and improved efficiency. Furthermore, Castells et al. (2012) reported that the provision of chopped grass hay improved total DMI in young calves. However, in all former studies (Thomas and Hinks, 1982; Coverdale et al., 2004; Castells et al., 2012), nutrient composition was not controlled across treatment diets. In the present study, all calves received a diet with the same nutrient composition; thus, differences in total DMI during the week after weaning and the trend for an improved apparent feed efficiency can be solely attributed to the physical form of forage present in the diet, which likely modified rumen characteristics, such as $\mathrm{pH}$ or development of the reticulorumen (Khan et al., 2011). It is likely that the trend toward an increased apparent feed efficiency herein was due to an improved rumen environment, as illustrated by increased DM and NDF digestion. Nevertheless, increases in BW associated with forage intake have been attributed to greater gut fill rather than carcass gain (Hill et al., 2008); thus, it would also be possible that the retention time and gut fill of calves consuming CRS would be greater than those of calves fed FN, and this would artificially increase BW and thus apparent feed efficiency. However, apparent fed efficiency tended to improve throughout the study, whereas DMI remained the same for most of the study except for the week after weaning; therefore, it seems that the trend toward an improvement in ap-

Table 3. Intake and BW gain of calves fed mixed rations containing chopped or ground hay from 2 to $56 \mathrm{~d}$ of age

\begin{tabular}{|c|c|c|c|c|c|c|}
\hline \multirow[b]{2}{*}{ Item } & \multicolumn{2}{|c|}{ Treatment $^{1}$} & \multirow[b]{2}{*}{ SE } & \multicolumn{3}{|c|}{$P$-value ${ }^{2}$} \\
\hline & CRS & $\mathrm{FN}$ & & Trt & Week & Trt $\times$ week \\
\hline $\mathrm{ADG}, \mathrm{kg} / \mathrm{d}$ & 0.94 & 0.89 & 0.03 & 0.34 & $<0.01$ & 0.17 \\
\hline Water intake ${ }^{3} \mathrm{~L} / \mathrm{d}$ & 3.51 & 3.34 & 0.30 & 0.68 & $<0.01$ & 0.11 \\
\hline Dry feed intake, $\mathrm{kg} / \mathrm{d}$ & 0.76 & 0.76 & 0.05 & 0.90 & $<0.01$ & 0.01 \\
\hline Milk replacer intake, $\mathrm{kg} / \mathrm{d}$ & 0.66 & 0.66 & 0.01 & 0.70 & $<0.01$ & 0.86 \\
\hline Total DMI, kg/d & 1.42 & 1.43 & 0.05 & 0.95 & $<0.01$ & 0.03 \\
\hline Gain-to-feed ratio, ${ }^{4} \mathrm{~kg} / \mathrm{kg}$ & 0.68 & 0.63 & 0.02 & 0.09 & $<0.01$ & 0.47 \\
\hline
\end{tabular}


Table 4. Sorting (\%) of nutrients during the last week of the milk-feeding stage (wk 7) and the week after weaning (wk 8) for calves fed mixed rations containing chopped or ground hay ${ }^{1}$

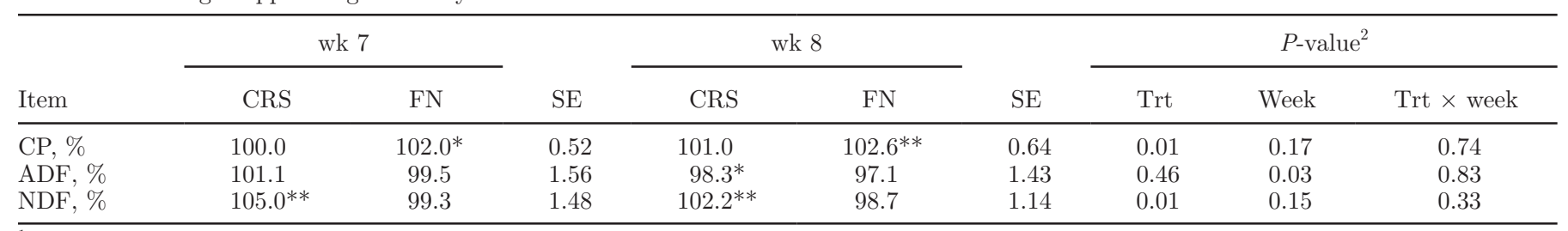

${ }^{1}$ Sorting $(\%)=100 \times($ nutrient intake/nutrient intake predicted). Sorting values equal to $100 \%$ indicate no sorting, those $<100 \%$ indicate selective refusals (sorting against), and those $>100 \%$ indicate preferential consumption (sorting for). Data are averaged over $7 \mathrm{~d}$ for each week for 10 calves per treatment.

${ }^{2}$ Trt $=$ effect of treatment [CRS $=$ mixture of $90 \%$ concentrate and $10 \%$ chopped ( 3 to $4 \mathrm{~cm}$ ) hay (coarse); FN = mixture of $90 \%$ concentrate and $10 \%$ ground $(2 \mathrm{~mm})$ hay $($ fine $)]$; week $=$ week effect; trt $\times$ week $=$ treatment $\times$ week interaction.

$* P<0.05$; sorting values differ from $100 \%$.

${ }^{* *} P<0.01$; sorting values differ from $100 \%$.

parent feed efficiency was due to improved digestion and was not due to gut fill.

As described in Table 1, the difference in particle size distribution of the CRS and FN diets obtained from the Penn State Particle Separator was minimal; the majority of particles in both diets $(94.2 \%$ of the CRS diet and $88.8 \%$ of the FN diet) were in the short particle size range $(<8 \mathrm{~mm}$ and $>1.18 \mathrm{~mm})$. Further, when ort samples were separated, most particles $(>88.2 \%)$ also fell in the short $(<8 \mathrm{~mm}$ and $>1.18 \mathrm{~mm})$ fraction. Given the similarities in particle size within both treatment diets, it was not possible to assess sorting for ration components by using particle size analyses. Thus, only sorting for specific nutrients was calculated (Table 4). Calves on the CRS treatment sorted to a greater extent for NDF than calves on the FN treatment, whereas calves on the FN treatment sorted to a greater extent for $\mathrm{CP}$ than calves on the CRS treatment. Given the nutrient composition of hay and concentrate (Table 1), these results suggest that calves fed CRS were sorting for hay instead of concentrate, whereas calves fed FN

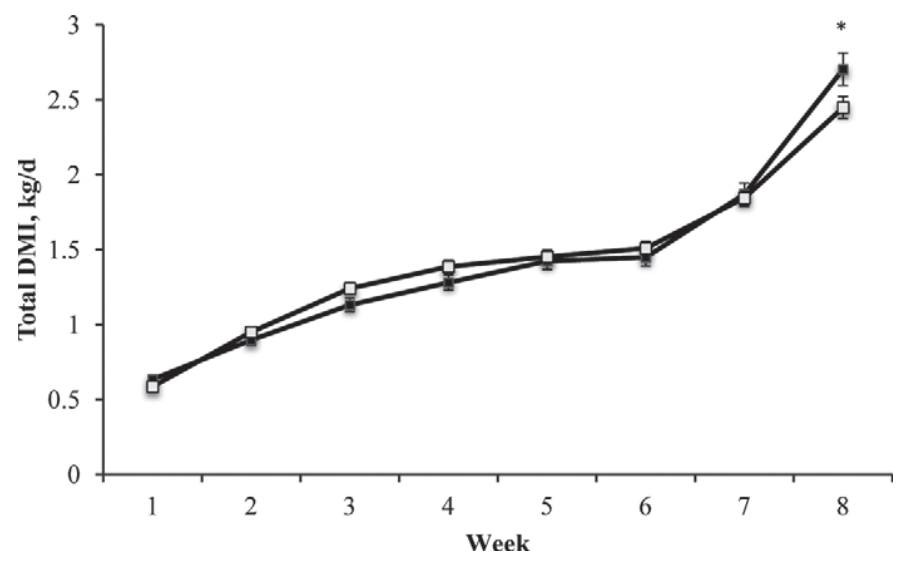

Figure 1. Total DMI (mixture and milk replacer; g/d) of calves fed mixed rations containing chopped $(\square)$ and ground $(\square)$ hay. An asterisk $(*)$ indicates total DMI between treatments differs at $P<0.05$. were sorting for concentrate instead of hay. This result is interesting, given that previous studies have shown that both cattle (e.g., DeVries et al., 2007) and calves (e.g., Miller-Cushon and DeVries, 2011) sort against NDF. The present result suggests that preference for the forage component of a mixed ration may depend on the particle size.

Although sorting of nutrients differed between treatments for both NDF and CP, actual differences in nutrient intake were observed only for NDF. No differences were observed in $\mathrm{CP}$ and ADF consumption between calves fed CRS and FN during the last 2 wk of the study (wk 7 and 8; Table 5). However, calves fed CRS had greater NDF consumption than calves fed FN. Furthermore, calves fed CRS tended to consume more NDF than calves fed FN (719.2 vs. $610.5 \pm 25.84$; respectively) during the last week of study (wk 8).

\section{Animal Behavior}

Total times devoted to performing each recorded behavior are reported in Table 6. No differences were found in time spent standing, lying, feeding, ruminating, drinking, or head butting between treatments. Rumination times recorded herein are lower than those reported previously (Porter et al., 2007; Castells et al., 2012), which was probably due to the time when rumination was recorded $(1 \mathrm{~h}$ after MR and $1 \mathrm{~h}$ after solid feed was offered). Calves receiving the FN treatment spent more time performing nonnutritive oral behaviors than calves receiving the CRS treatment. Nonnutritive oral behaviors are often considered indicators of poor welfare because they are thought to be related to frustrated feeding motivation caused by a thwarted ability to forage (Redbo, 1990; Redbo and Nordblad, 1997). Researchers have previously reported that restricted roughage allowance has a considerable effect on the duration and frequency of bouts of stereotypies 
Table 5. Nutrient intakes during the last week of the milk-feeding stage (wk 7) and the first week after weaning (wk 8) for calves fed mixed rations containing chopped or ground hay ${ }^{1}$

\begin{tabular}{|c|c|c|c|c|c|c|}
\hline \multirow[b]{2}{*}{ Item } & \multicolumn{2}{|c|}{ Treatment $^{2}$} & \multirow[b]{2}{*}{$\mathrm{SE}$} & \multicolumn{3}{|c|}{$P$-value ${ }^{3}$} \\
\hline & CRS & $\mathrm{FN}$ & & Trt & Week & Trt $\times$ week \\
\hline $\mathrm{CP}, \mathrm{g} / \mathrm{d}$ & 486.8 & 466.0 & 21.25 & 0.50 & $<0.01$ & 0.18 \\
\hline $\mathrm{ADF}, \mathrm{g} / \mathrm{d}$ & 295.1 & 284.0 & 11.87 & 0.52 & $<0.01$ & 0.20 \\
\hline $\mathrm{NDF}, \mathrm{g} / \mathrm{d}$ & 587.6 & 507.6 & 21.87 & 0.02 & $<0.01$ & 0.09 \\
\hline
\end{tabular}

${ }^{1}$ Data are averaged by week for 10 calves on each treatment.

${ }^{2} \mathrm{CRS}=$ calves offered a mixture of $90 \%$ concentrate and $10 \%$ chopped $(3$ to $4 \mathrm{~cm}$ ) hay (coarse); FN $=$ calves offered a mixture of $90 \%$ concentrate and $10 \%$ ground $(2 \mathrm{~mm}$ ) hay (fine).

${ }^{3}$ Trt $=$ treatment effect; week $=$ week effect; trt $\times$ week $=$ treatment $\times$ week interaction.

in heifers (Redbo and Nordblad, 1997; Phillips, 2004). Furthermore, Castells et al. (2012) reported that calves fed a starter concentrate and ryegrass hay devoted less time to performing nonnutritive oral behaviors than calves deprived of forage. Calves offered CRS tended to spend more time idling than calves offered FN (Table 6 ), which could be attributed, in part, to the increased time devoted to performing nonnutritive activities in calves fed FN compared with those fed CRS. The present results suggest that forage particle size, in addition to forage allowance, plays an important role in reducing nonnutritive oral behaviors in young calves; thus, providing calves with chopped forage particles may improve welfare.

\section{CONCLUSIONS}

The provision of chopped hay mixed with a starter concentrate improves total DMI and nutrient digestibility during the week after weaning as compared with the addition of ground hay to a starter concentrate. Furthermore, the provision of chopped hay reduces nonnutritive oral behaviors and tends to improve apparent feed efficiency during the first weeks of life compared with calves receiving ground hay.

\section{ACKNOWLEDGMENTS}

We thank the staff and students at the University of Guelph Kemptville Campus Dairy Education and Research Centre. In particular, we thank B. Kitts, M. Bruce, and M. Aarnoudse for their technical assistance. We also acknowledge the financial support received from the Instituto Nacional de Investigación y Tecnología Agraria y Alimentarias (INIA, Madrid, Spain). Research support, including the gracious provision of starter feed, from Shur-Gain (Nutreco Canada Inc., Guelph, ON, Canada), is greatly appreciated. This project was also supported by a Natural Sciences and Engineering Research Council of Canada (NSERC, Ottawa, ON, Canada) Discovery Grant (T. J. DeVries) and an Ontario Ministry of Agriculture, Food and Rural Affairs (OMAFRA, Guelph, ON, Canada)/University of Guelph Production Systems research grant. This project was also supported through contributions from the Canadian Foundation for Innovation (CFI, Ottawa,

Table 6. Effect of type of feed exposure on average time [in minutes or as a proportion of total activities (\% within parentheses)] that calves devoted to performing different activities (standing or lying) and behaviors per day during the $28 \mathrm{~h}$ of observations (2 h/d) conducted 2 wk before weaning (wk 6) and 1 wk after weaning (wk 8)

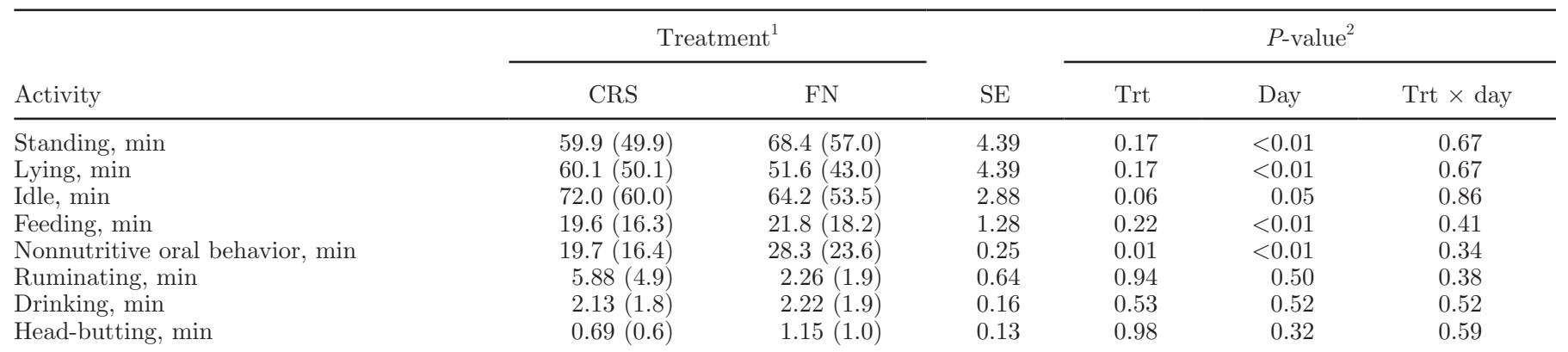

$\overline{{ }^{1} \mathrm{CRS}}=$ mixture of $90 \%$ concentrate and $10 \%$ chopped $(3$ to $4 \mathrm{~cm})$ hay (coarse); $\mathrm{FN}=$ mixture of $90 \%$ concentrate and $10 \%$ ground $(2 \mathrm{~mm})$ hay (fine).

${ }^{2}$ Trt $=$ effect of treatment; day $=$ effect of day of sampling; trt $\times$ day $=$ interaction between treatment and day. 
ON, Canada) and the Ontario Research Fund (Ministry of Research and Innovation, Toronto, ON, Canada).

\section{REFERENCES}

AOAC International. 2000. Official Methods of Analysis. 17th ed. Vol. 1. AOAC Int., Arlington, Virginia.

Bach, A., A. Giménez, J. L. Juaristi, and J. Ahedo. 2007. Effects of physical form of a starter for dairy replacement calves on feed intake and performance. J. Dairy Sci. 90:3028-3033.

Baldwin, R. L. VI, K. R. McLeod, J. L. Klotz, and R. N. Heitmann. 2004. Rumen development, intestinal growth and hepatic metabolism in the pre- and post-weaning ruminant. J. Dairy Sci. 87(E Suppl.): E55-E65.

Beharka, A. A., T. G. Nagaraja, J. L. Morrill, G. A. Kennedy, and R. D. Klemm. 1998. Effect of form of the diet on anatomical, microbial and fermentative development of the rumen of neonatal calves. J. Dairy Sci. 81:1946-1955.

Bull, L. S., L. J. Busch, J. D. Friend, B. Harris Jr., and E. W. Jones. 1965. Incidence of ruminal parakeratosis in calves fed different rations and its relation to volatile fatty acids absorption. J. Dairy Sci. 48:1449-1456.

Castells, Ll., A. Bach, G. Araujo, C. Montoro, and M. Terré. 2012. Effect of different forage sources on performance and feeding behavior of Holstein calves. J. Dairy Sci. 95:286-293.

CCAC (Canadian Council on Animal Care). 2009. Guidelines on the Care and Use of Farm Animals in Research, Teaching and Testing. Can. Counc. Anim. Care, Ottawa, ON, Canada.

Clarke, R. T. J., and C. S. W. Reid. 1974. Foamy bloat of cattle. A review. J. Dairy Sci. 57:753-785.

Coverdale, J. A., H. D. Tyler, J. D. Quigley III, and J. A. Brumm. 2004. Effect of various levels of forage and form of diet on rumen development and growth in calves. J. Dairy Sci. 87:2554-2562.

Davis, C. L., and J. K. Drackley. 1998. The Development Nutrition and Management of the Young Calf. Iowa State Univ. Press, Ames.

DeVries, T. J., K. A. Beauchemin, and M. A. G. von Keyserlingk. 2007. Dietary forage concentrate affects the feed sorting behavior of lactating dairy cows. J. Dairy Sci. 90:5572-5579.

Hill, T. M., H. G. Bateman, J. M. Aldrich, and R. L. Schlotterbeck. 2008. Effects of the amount of chopped hay or cottonseed hulls in a textured calf starter on young calf performance. J. Dairy Sci. 91:2684-2693.

Hill, T. M., H. G. Bateman II, J. M. Aldrich, and R. L. Schlotterbeck. 2010. Effects of milk replacer program on digestion of nutrients in dairy calves. J. Dairy Sci. 93:1105-1115.

Hinders, R. G., and F. G. Owen. 1965. Relation of ruminal parakeratosis development to volatile fatty acid absorption. J. Dairy Sci. 48:1069-1073.

Hodgson, J. 1971. The development of solid food intake in calves. I The effect of previous experience of solid food, and the physical form of diets, on the development of food intake after weaning. Anim. Prod. 13:15-24.

Kertz, A. F. 2007. Letter to the Editor: Pelleted calf starter with straw access can confound results: A comment on Bach et al. (2007). J. Dairy Sci. 90:4924.

Khan, M. A., D. M. Weary, D. M. Veira, and M. A. G. von Keyserlingk. 2012. Postweaning performance of heifers fed starter with and without hay during the milk-feeding period. J. Dairy Sci. 95:3970-3976.

Khan, M. A., D. M. Weary, and M. A. G. von Keyserlingk. 2011. Hay intake improves performance and rumen development of calves fed higher quantities of milk. J. Dairy Sci. 94:3547-3553.

Kononoff, P. J., A. J. Heinrichs, and D. R. Buckmaster. 2003. Modification of the Penn State forage and total mixed ration particle separator and the effects of moisture content on its measurements. J. Dairy Sci. 86:1858-1863.

Miller-Cushon, E. K., and T. J. DeVries. 2011. Effect of early feed type exposure on diet-selection behavior of dairy calves. J. Dairy Sci. 94:342-350.

Phillips, C. J. C. 2004. The effects of forage provision and group size on the behavior of calves. J. Dairy Sci. 87:1380-1388.

Porter, J. C., R. G. Warner, and A. F. Kertz. 2007. Effect of fiber level and physical form of starter on growth and development of dairy calves fed no forage. Prof. Anim. Sci. 23:395-400.

Redbo, I. 1990. Changes in duration and frequency of stereotypies and their adjoining behaviours in heifers, before, during and after the grazing period. Appl. Anim. Behav. Sci. 26:57-67.

Redbo, I., and A. Nordblad. 1997. Stereotypies in heifers are affected by feeding regime. Appl. Anim. Behav. Sci. 53:193-202.

Sander, E. G., H. N. Warner, H. N. Harrison, and J. K. Loosli. 1959. The stimulatory effect of sodium butyrate and sodium propionate on the development of rumen mucosa in the young calf. J. Dairy Sci. $42: 1600-1605$.

Stobo, I. J. F., J. H. B. Roy, and H. J. Gaston. 1966. Rumen development in the calf. 1. The effect of diets containing different proportions of concentrates to hay on rumen development. Br. J. Nutr. 20:171-188.

Suárez, B. J., C. G. Van Reenen, N. Stockhofe, J. Dijkstra, and W. J. J. Gerrits. 2007. Effect of roughage source and roughage to concentrate ratio on animal performance and rumen development in veal calves. J. Dairy Sci. 90:2390-2403.

Tamate, H., A. D. McGilliard, N. L. Jacobson, and R. Getty. 1962. Effect of various diets on the anatomical development of the stomach in the calf. J. Dairy Sci. 45:408-420.

Terré, M., M. Devant, and A. Bach. 2007. Effect of level of milk replacer fed to Holstein calves on performance during the preweaning period and starter digestibility at weaning. Livest. Sci. 110:82-88.

Thomas, D. B., and C. E. Hinks. 1982. The effect of changing the physical form of roughage on the performance of the early-weaned calf. Anim. Prod. 35:375-384.

van Ackeren, C., H. Steingaß, K. Hartung, R. Funk, and W. Drochner. 2009. Effect of roughage level in a total mixed ration on feed intake, ruminal fermentation patterns and chewing activity of early weaned calves with ad libitum access to grass hay. Anim. Feed Sci. Technol. 153:48-59.

Van Soest, P. J., J. B. Robertson, and B. A. Lewis. 1991. Methods for dietary fiber, neutral detergent fiber non-starch polysaccharide in relation to animal nutrition. J. Dairy Sci. 74:3583-3597.

Warner, R. G. 1991. Nutritional factors affecting the development of a functional ruminant - A historical perspective. Pages 1-12 in Proc. Cornell Nutr. Conf. Cornell Nutrition Conference Committee, Ithaca, NY.

Warner, R. G., W. P. Flatt, and J. K. Loosli. 1956. Dietary factors influencing the development of the animal's stomach. J. Agric. Food Chem. 4:788-792. 